\title{
EFFECTS OF DRIP IRRIGATION SYSTEM FOR ENHANCING RICE (ORYZA SATIVA L.) YIELD UNDER SYSTEM OF RICE INTENSIFICATION MANAGEMENT
}

\author{
RAO, K. V. R. ${ }^{*}$ - GANGWAR, S. - KESHRI, R. - CHOURASIA, L. - BAJPAI, A. - SONI, K \\ Irrigation and Drainage Engineering Division, ICAR-Central Institute of Agricultural \\ Engineering, Bhopal, Madhya Pradesh, India \\ *Corresponding author \\ e-mail: kvramanarao1970@gmail.com
}

(Received $8^{\text {th }}$ Nov 2016; accepted $16^{\text {th }}$ Mar 2017)

\begin{abstract}
To increase both water productivity and rice production, research was carried out at the Central Institute of Agricultural Engineering, Bhopal, India, to evaluate the use of drip irrigation together with modifications in rice crop geometry and other cultural practices. Experiments were conducted with five alternative treatments: $\mathrm{T}_{1}$ : Conventional paddy cultivation under continuous flooding, $\mathrm{T}_{2}$ : System of Rice Intensification (SRI) methods which include alternate wetting and drying, $\mathrm{T}_{3}$ : SRI methods with dripirrigation, the emitters being spaced at $20 \mathrm{~cm}, \mathrm{~T}_{4}$ : SRI methods with drip emitters spaced at $30 \mathrm{~cm}$, and $\mathrm{T}_{5}$ : SRI methods with drip emitters spaced at $40 \mathrm{~cm}$. Greatest plant height and root length were recorded with SRI under drip irrigation at $20 \mathrm{~cm}$ spacing (T3). Yield and yield-contributing parameters were also significantly higher with this $\mathrm{T} 3$ treatment as compared with conventional practice (TI): productive tillers $/ \mathrm{m}^{2}$, number of grains per panicle, average panicle length and weight, average grain yield (7 t/ha), and harvest index. Superior performance of the T3 treatment in terms of water productivity and waterenergy productivity was also recorded. Among the drip-irrigated treatments, however, there was no statistically significant difference in grain yield between $\mathrm{T} 3$ and $\mathrm{T} 4$ treatments, indicating that drippers spaced at $30 \mathrm{~cm}$ could be recommended to lower the cost of the drip system installation.
\end{abstract}

Keywords: water productivity, plant growth parameters, yield contributing parameters, water energy productivity, economics

\section{Introduction}

Rice is the most important global food crop. Year-to-year fluctuations in its production have a direct bearing on food security and on price inflation in the world market. Given its continuing population growth, India should be producing 1.7 million tonnes of additional rice every year to ensure national food security (Dass and Chandra, 2013). Hence, there is a need to increase sustainably the yields and productivity of rice cultivation, doing this to the extent possible with reduced inputs and with less exploitation of natural resources to feed the increasing global population. This is a challenge for rice-growing countries around the world.

For producing rice at present with traditional irrigation techniques, large quantities of water are being used to flood paddy fields with standing water $2-5 \mathrm{~cm}$ deep at the different stages of crop growth. Studies have indicated that 3000-5000 liters of water are often used to produce $1 \mathrm{~kg}$ of rice (Satyanarayana et al., 2007), but this includes water applications which are clearly excessive. Water requirements for flooded rice production are currently considered to average a little over 1,400 liters per $\mathrm{kg}$ of rice(www.knowledgebank.irri.org/step-by-step-production/growth/water-management). This is about three times more than for growing wheat and maize (Riaz, 2001).

Water scarcity is a major challenge affecting rice production all around the globe. More than $80 \%$ of the fresh water resources in Asia are used for agriculture, of which 
about half of the total irrigation water is used for rice production (Dawe et al., 2003). Future rice production will depend on improvements in water use efficiency for growing rice crops. A large-scale evaluation in Indonesia with over 11,000 on-farm comparison trials conducted over six seasons reported a $78 \%$ increase in paddy rice yields with about $40 \%$ reduction in water and with lower costs of production when using the methods of the System of Rice Intensification (SRI), which include alternate wetting and drying of paddy fields rather than flooding as done with conventional practices (Sato and Uphoff, 2007). SRI methods have been validated in over 50 countries, and given the scarcity of water resources in so many countries and the evident yield advantages with SRI management, probably more than 10 million farmers are already using some or all of its recommended practices (http://sri.cals.cornell.edu).

Substantial water savings with higher paddy yields using SRI methods have been confirmed in a meta-analysis of 27 published studies across 8 countries, an average $35 \%$ reduction in irrigation water per hectare and a $22 \%$ reduction in total water (irrigation plus rainfall) (Jagannath et al., 2013). But these comparisons were all made with modified regimes of flood irrigation. Possibly there could be even greater savings of irrigation water and more gains in water productivity with employment of drip irrigation technology. And if such benefits are possible, how can the productivity of drip irrigation be optimized? These are important considerations for enhancing both the productivity and sustainability of irrigated rice cultivation, and it is these concerns that gave impetus to the research whose findings are reported here.

\section{Materials and Methods}

\section{Study areas}

The research work was carried out at the Central Institute of Agricultural Engineering, Bhopal. Soils of the experimental site are classified as heavy clay soils with clay content varying between 49.7 to $53.7 \%$ and with the field capacity ranging from 28.5 to $31 \%$. Which was situated at north of Bhopal at $77^{\circ} 24^{\prime} 10^{\prime \prime} \mathrm{E}, 23^{\circ} 18^{\prime} 35^{\prime \prime} \mathrm{N}$ at an elevation of $495 \mathrm{~m}$ above mean sea level.

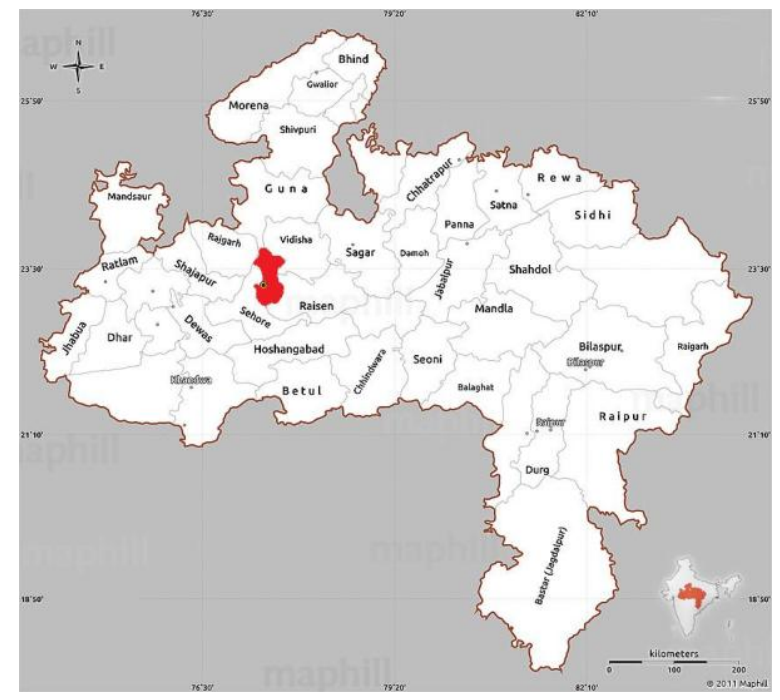

Figure 1. The map of Madhya Pradesh State showing the Local Government Areas (red colour pointing to the study areas) 
The climate of Bhopal is pleasant throughout the year. Generally the climate of the study area is hot and humid in nature. The annual rainfall in the region is about 1200 $\mathrm{mm}$. Eighty percent of the total rainfall occurs during the month of June to September in almost every year which is popularly known as monsoon rainfall. The summer months from March to May are very hot and humid, and temperature often rises above $40^{\circ} \mathrm{C}$.

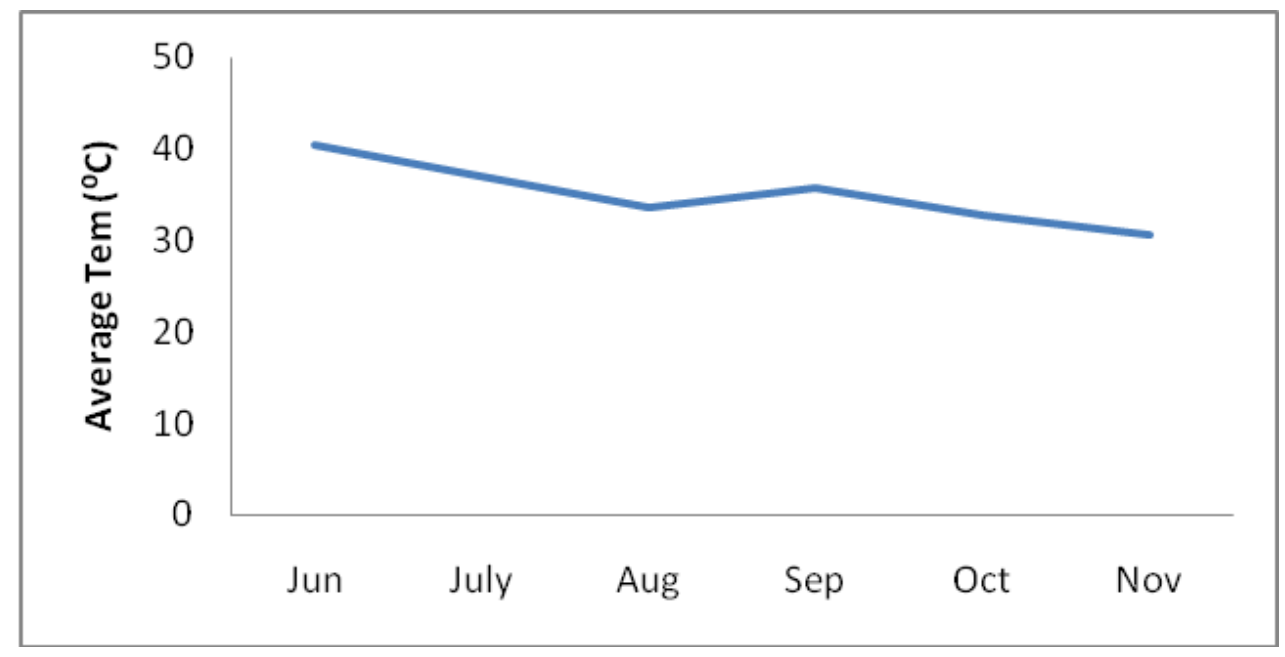

Figure 2. Average temperature $\left({ }^{\circ} \mathrm{C}\right)$ of ten years

Five treatments were considered in the study: $\mathrm{T}_{1}$ : Conventional practices with continuous flooding, $\mathrm{T}_{2}$ : System of Rice Intensification (SRI) crop and water management methods, $\mathrm{T}_{3}$ : SRI management with drip irrigation emitters spaced at 20 $\mathrm{cm}, \mathrm{T}_{4}$ : SRI with drip emitters spaced at $30 \mathrm{~cm}$ and $\mathrm{T}_{5}$ : SRI with drip emitters spaced at $40 \mathrm{~cm}$. Puddling was carried out in the T1 and T2 plots, but the T1 plots had continuous flooding, while T2 plots had alternate wetting and drying. Young seedlings 10 days old were transplanted manually in the T2, T3, T4 and T5 treatments at $30 \mathrm{x} 30 \mathrm{~cm}$ spacing with single plants per hill and a seed rate of $10 \mathrm{~kg} \mathrm{ha}^{-1}$. Transplanting in $\mathrm{T} 1$ was carried out on the $30^{\text {th }}$ day after seeding, and 3-4 plants per hill were transplanted at a spacing of $15 \times 5 \mathrm{~cm}$ spacing, with a seed rate about $100 \mathrm{~kg} \mathrm{ha}^{-1}$. The dates of transplanting for all the treatments were the same. Each treatment plot was replicated four times, and each plot was surrounded by bunds $0.5 \mathrm{~m}$ wide in order to arrest any lateral seepage and nutrient diffusion from adjoining treatments.

Inorganic fertilizers were applied to all the plots with the recommended doses of 150 $\mathrm{kg} \mathrm{N}, 100 \mathrm{~kg} \mathrm{P}$ and $120 \mathrm{~kg} \mathrm{~K}$ per ha in the form of Urea, Di-Ammonium Phosphate (DAP) and Murate of Potash (MOP), respectively. Half of the recommended dose of nitrogen and all of the phosphorus and potash were applied at sowing, while the remaining $\mathrm{N}$ was applied at the time of tillering through broadcasting in the T1 and T2 treatments and through the drip irrigation system in T3, T4 and T5 treatments using water-soluble fertilizers. Rates and kinds of soil nutrient supplementation were thus not a variable in this experiment.

During the crop growing period, T1 treatment plots were under fully ponded conditions (to a depth of $4-5 \mathrm{~cm}$ ) for a total of 34 days during the growing season, while T2 plots were under ponded conditions for a total of 25 days during their alternating periods of drying and wetting of the plots at six-day intervals. The drip-irrigated 
treatments T3, T4 and T5 were operated for $15 \mathrm{~min}, 23 \mathrm{~min}$ and $30 \mathrm{~min}$, respectively, for a cumulative period of 60 days. Weeds were controlled by manual weeding after transplanting on the $20^{\text {th }}, 40^{\text {th }}, 60^{\text {th }}$ and $80^{\text {th }}$ days, so weed control was also not a variable evaluated in these trials even though mechanical, soil-aerating weeding is recommended as part of the recommended SRI protocol.

Monocrotophos (400 ml per acre) was applied for controlling stem borer at 25 DAS and Gandhi bug at 70 DAS in all treatments. Bacterial blight was controlled by the application of Streptocylin along with Copper Oxi-Chloride $(6 g+250 g$ per acre) at 30-35 DAS in rice.

At the time of transplanting, five plants were randomly selected from each plot to be used for recording plant height, number of tillers, number of effective tillers, root length, panicle length, and panicle weight, number of grains per panicle, 1000-grain weight, grain yield, and straw yield. The data collected were analyzed by using Fisher's analysis of variance technique, and a Randomized Block Design (RBD) test with the confidence level set at 5\% was used to compare the differences among treatment means (Steel et al., 1997).

\section{Results and Discussion}

\section{Plant growth parameters}

The influence of different treatments on rice crop growth parameters on the $60^{\text {th }}$ day after transplanting is given in Table 1, and the actual condition of the crop is shown in Plate 1. The different irrigation practices along with associated crop management had a significant effect on plant height. The greatest average plant height was recorded with treatment T3 $(76.45 \mathrm{~cm})$ possibly due to optimizing plant population and geometry under SRI with drip emitters spaced at $20 \mathrm{~cm}$ which gave more even distribution of water to the plants. Similarly, the greatest number of tillers $\mathrm{m}^{-2}$ area was also recorded under T3 (240.75), followed by T4 (232.50) and T5 (223.50). The lowest number of tillers was recorded with T1 (217.25). However, chlorophyll values as measured by a SPAD meter did not significantly vary across the different treatments. Root length was also greatest under T3 $(18.23 \mathrm{~cm})$, followed by T4 $(16.08 \mathrm{~cm})$, while the lowest root length was recorded under T1 $(14.10 \mathrm{~cm})$.

Table 1. Influence of growth parameters by different irrigation practices

\begin{tabular}{ccccc}
\hline Treatments & $\begin{array}{c}\text { Plant height at } \\
\text { 60 DAT }(\mathrm{cm})\end{array}$ & $\begin{array}{c}\text { Number of tillers } \\
\text { at 60 DAT }\end{array}$ & $\begin{array}{c}\text { SPAD } \\
\text { Values }\end{array}$ & $\begin{array}{c}\text { Root length } \\
(\mathrm{cm})\end{array}$ \\
\hline T1 & 73.45 & 217.25 & 44.81 & 14.10 \\
T2 & 73.60 & 218.20 & 44.67 & 15.30 \\
T3 & 76.45 & 240.75 & 45.12 & 18.23 \\
T4 & 75.80 & 232.50 & 45.00 & 16.08 \\
T5 & 74.70 & 223.50 & 44.85 & 15.50 \\
\hline SEM \pm & 0.85 & 2.92 & 0.68 & 0.68 \\
CD $(\mathrm{p}=0.05)$ & 2.51 & 8.60 & NS & 2.01 \\
\hline
\end{tabular}



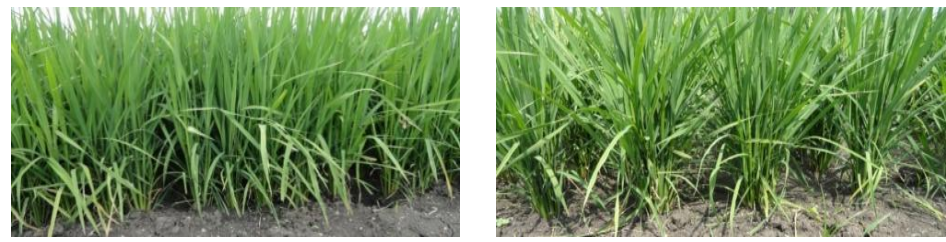

Conventional paddy (L), SRI (R)
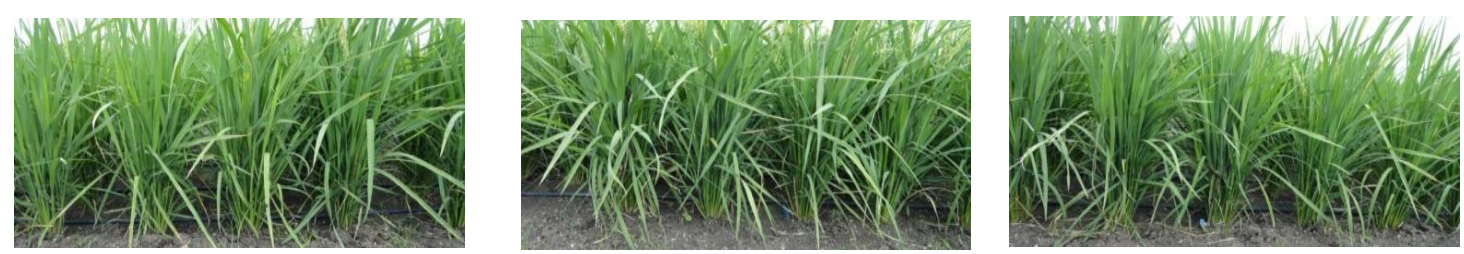

Drip-irrigated paddy emitters spaced at $20 \mathrm{~cm}(\mathrm{~L}), 30 \mathrm{~cm}(\mathrm{M})$ and $40 \mathrm{~cm}(\mathrm{R})$ at 60 dayI (R)

Plate 1. Experimental crops under different cultivation and irrigation practices at 60 days

Intermittent irrigation creates favourable soil physical, chemical and biological properties that support plant growth under mostly aerobic soil conditions, encouraging deeper rooting depth and creating favourable micro-climates in the soil, which support abundance of micro-organisms and more availability of micro-nutrients. Better root systems provide good anchorage for the plants and sustain effective use of applied fertilizers by checking losses from leaching (Stoop et al., 2002). Optimum availability of soil moisture plays a key role in the processes of mineralization and solubilisation, affecting the availability and uptake of nutrients, and contributing to plant growth and yield (Venkateswarlu et al., 1997). Greater root capacity also supports a higher photosynthetic rate by supplying sufficient amounts of nutrients to the shoots, thereby enabling high productivity (Osaki et al., 1997). Sharda et al. (2016) observed in their study that root length and density were maximum in the drip irrigated crop than flood irrigated crop.

\section{Yield-contributing parameters}

It has been seen in many studies that flooding is not the most favourable condition for growing rice crops (Belder et al., 2004; Sahrawat, 2000; Gani, 2001; Borrel et al., 1997). The findings of the present study confirm that different irrigation methods and regimes have a significant influence on crop yield parameters. System of Rice Intensification methods adapted with drip irrigation emitters spaced $20 \mathrm{~cm}$ apart gave the highest number of productive tillers at maturity $\left(264.75 \mathrm{~m}^{-2}\right)$, also the highest number of grains per panicle (161.75), longest panicle length $(27.52 \mathrm{~cm})$, and highest panicle weight $(3.41 \mathrm{~g})$, as seen in Table 2 .

These findings are consistent with the results reported by Yang et.al. (2004) indicating that intermittent irrigation and maintaining moist, mostly aerobic soils not only enhances tillering but also the root system's development and functioning. However, 1000-grain weight and straw yield (t/ha) were not found to differ significantly among the five treatments. Treatment $\mathrm{T} 3$ also had a significant effect on grain yield and 
on the harvest index. SRI methods with drip at $20 \mathrm{~cm}$ spacing gave the highest grain yield, $7.07 \mathrm{t} \mathrm{ha}^{-1}$, while conventional practices (T1) with flood irrigation, older seedlings, and greater plant density resulted in the lowest grain yield, $3.14 \mathrm{t} \mathrm{ha}^{-1}$. Harvest index calculated for T3 was the highest (61.9), while that for T1 was the lowest (40.7), a very large difference.

Table 2. Yield and yield-contributing characters influenced by different irrigation practices

\begin{tabular}{ccccccccc}
\hline Treatments & $\begin{array}{c}\text { Number of } \\
\text { effective } \\
\text { tillers }\left(\text { per } \mathrm{m}^{2}\right)\end{array}$ & $\begin{array}{c}\text { Number of } \\
\text { grains per } \\
\text { panicle }\end{array}$ & $\begin{array}{c}\text { Panicle } \\
\text { length } \\
(\mathrm{cm})\end{array}$ & $\begin{array}{c}\text { Panicle } \\
\text { weight } \\
(\mathrm{g})\end{array}$ & $\begin{array}{c}\text { 1000 grain } \\
\text { weight }(\mathrm{g})\end{array}$ & $\begin{array}{c}\text { Grain } \\
\text { yield } \\
(\mathrm{t} / \mathrm{ha})\end{array}$ & $\begin{array}{c}\text { Straw } \\
\text { yield } \\
(\mathrm{t} / \mathrm{ha})\end{array}$ & $\begin{array}{c}\text { Harvest } \\
\text { index } \\
(\%)\end{array}$ \\
\hline T1 & 222.25 & 133.50 & 25.67 & 2.78 & 32.30 & 3.14 & 4.30 & 40.73 \\
T2 & 242.0 & 141.0 & 25.97 & 3.02 & 32.96 & 4.04 & 4.18 & 48.08 \\
T3 & 264.75 & 161.75 & 27.52 & 3.41 & 33.51 & 7.07 & 4.60 & 61.93 \\
T4 & 256.25 & 151.5 & 26.96 & 3.37 & 32.71 & 6.72 & 4.34 & 60.98 \\
T5 & 253.0 & 149.0 & 25.87 & 3.16 & 32.59 & 5.95 & 4.43 & 57.72 \\
\hline SEM \pm & 4.49 & 4.09 & 0.40 & 0.07 & 0.41 & 0.31 & 0.13 & 2.57 \\
CD (p=0.05) & 13.25 & 12.07 & 1.18 & 0.22 & NS & 0.90 & 0.39 & 7.59 \\
\hline
\end{tabular}

It is worth noting that the $1^{\text {st }}, 2^{\text {nd }}, 5^{\text {th }}$ and $7^{\text {th }}$ sets of bar graphs in Figure 3 all follow the same sequential pattern: $\mathrm{T} 3>\mathrm{T} 4>\mathrm{T} 5>\mathrm{T} 2>\mathrm{T} 1$. This pattern is seen throughout the data gathered and analyzed. Detailed measurements made of grain characteristics and milling quality (grain length, breadth, eccentricity, perimeter and milling efficiency) revealed no significant differences when the data were analyzed statistically (data not shown). However, there was a rather consistent rank-ordering of the results seen across all these measurements: $\mathrm{T} 3>\mathrm{T} 4>\mathrm{T} 5>\mathrm{T} 2>\mathrm{T} 1$.

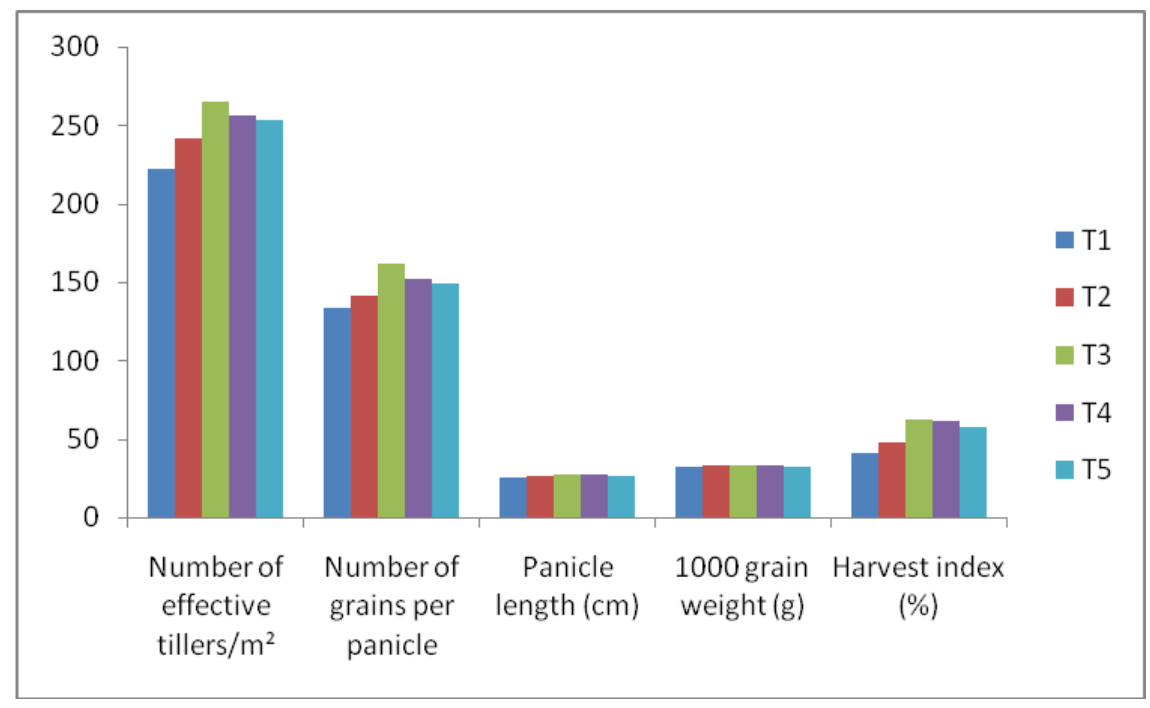

Figure 3. Yield-contributing characteristics as influenced by different irrigation practices

\section{Water productivity and water-energy productivity}

Efficient water management is key to higher paddy yields and greater net income with the System of Rice Intensification as this key input influences the effects of other 
inputs as well. Water productivity and water-energy productivities for the selected treatments were analyzed and are presented in Figure 4. Water productivity is the amount of grain yield obtained per unit of irrigation water supplied to the crop. Waterenergy productivity is the amount of grain yield that is obtained from a unit of energy $(\mathrm{kWh})$ consumed during the irrigation.

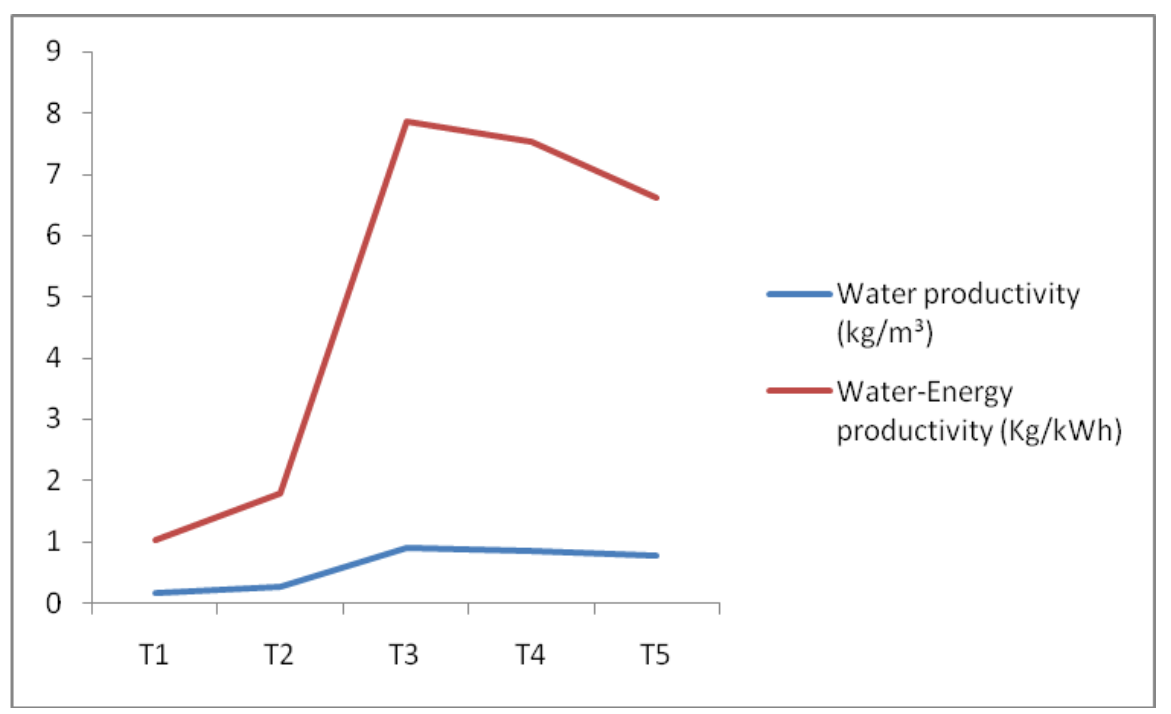

Figure 4. Water productivity ( $k g$ of rice per $m^{3}$ of irrigation water) and water-energy productivity ( $\mathrm{kg}$ of rice per kilowatt-hour of electricity) as influenced by the irrigation practices evaluated

Water productivity was found highest under T3 $\left(0.90 \mathrm{~kg} \mathrm{~m}^{-3}\right)$ followed by $\mathrm{T} 4(0.86$ $\left.\mathrm{kg} \mathrm{m}^{-3}\right)$. The lowest water productivity was recorded under $\mathrm{T} 1\left(0.16 \mathrm{~kg} \mathrm{~m}^{-3}\right)$, with no difference between T4 and T3 in terms of water productivity. Similarly, the highest water-energy productivity of was observed under treatment $\mathrm{T} 3\left(7.85 \mathrm{~kg} \mathrm{kWh}^{-1}\right)$, with the lowest productivity found for treatment $\mathrm{T} 1\left(1.02 \mathrm{~kg} \mathrm{kWh}^{-1}\right)$. This difference was highly significant statistically. However, among the treatments T3, T4 and T5, the calculated differences in water productivity and water-energy productivity were not significant.

\section{Economics of drip-irrigated paddy}

In the present study, the economics of drip-irrigated paddy were compared with conventional paddy cultivation practices and with standard System of Rice Intensification. The annual cost of drip irrigation system was calculated with the assumption that the life of the physical infrastructure would be 10 years with 10 per cent annual depreciation. The cost components considered included seeds, fertilizer, labour, electricity charges per unit, farm yard manure, harvesting and threshing. Uniform cost values were considered for all the treatments depending upon the respective quantity of input in each treatment.

The findings of the study indicated that the highest net return (\$2442/ha/year) and B:C (3.23) ratio can be obtained under SRI management with drip irrigation emitters spaced at $20 \mathrm{~cm}$, followed by SRI with drip irrigation emitters spaced at $30 \mathrm{~cm}$ (Table $3)$. The lowest net return ( $\$ 853 /$ ha/year) and lowest Benifit: Cost (2.18) ratio was 
obtained with conventional practice of paddy cultivation. Based upon his research in Madagascar, Andrianaivo (2002) reported that optimal water use can enhance returns from System of Rice Intensification with enhanced labour productivity and far higher net income than traditional methods for the cultivation of rice. The findings of the present study are consistent with Andrianaivo's analysis and that of many other studies.

Table 3. Economic and water productivity of paddy cultivation with drip irrigation systems over conventional system

\begin{tabular}{ccccc}
\hline Treatments & $\begin{array}{c}\text { Annual cost of } \\
\text { cultivation } \\
\text { (\$/ha/year) }\end{array}$ & $\begin{array}{c}\text { Gross monetary } \\
\text { return }(\$ / \text { ha/year) }\end{array}$ & $\begin{array}{c}\text { Net monetary } \\
\text { return }(\$ / \text { ha/year })\end{array}$ & $\begin{array}{c}\text { Benifit:Cost } \\
\text { ratio }\end{array}$ \\
\hline $\mathrm{T}_{1}$ & 1125 & 2170 & 1045 & 1.92 \\
$\mathrm{~T}_{2}$ & 920 & 2769 & 1849 & 3.00 \\
$\mathrm{~T}_{3}$ & 822 & 4782 & 3960 & 5.81 \\
$\mathrm{~T}_{4}$ & 796 & 4562 & 3766 & 5.73 \\
$\mathrm{~T}_{5}$ & 782 & 4041 & 3258 & 5.16 \\
\hline
\end{tabular}

Assumptions: Revenue received is $\$ 667$ per tonne of grain produced, and Rs. 17 per tonne for straw yield, based on prevailing market prices

\section{Conclusions}

The present study found consistent evidence that the adoption of drip irrigation combined with paddy transplanted and managed according to System of Rice Intensification practices offers substantial agronomic and economic advantages. Plant growth and yield-contributing parameters such as effective tillers, number of panicles $\mathrm{m}^{-2}$, and grain yield were found to be significantly higher in drip-irrigated treatments. Apart from higher yield, water productivity and water-energy productivity were both higher in the case of drip-irrigated paddy cultivation with young single seedlings transplanted at $30 \times 30 \mathrm{~cm}$ spacing with drip emitters spaced at $20 \mathrm{~cm}$.

Among the drip-irrigated treatments, there was no significant difference in grain yield between the T3 and T4 treatments which indicate that spacing drippers at $30 \mathrm{~cm}$ can be recommended as the cost of installing a drip system would be relatively cheaper with more widely-spaced drippers. These results should be further tested with further experimentation and evaluation because the implications of this work could be rather far-reaching. The evidence assembled and analyzed here suggests that System of Rice Intensification crop management with drip irrigation is a promising adaptation for reducing the rice-crop's demand for water and energy, which are increasingly demanded and costly, while at the same time it raises grain yield. However, long-term, multilocation trials will be needed to arrive at percentages of water and energy saving that are achievable under varied and specific conditions.

Acknowledgements. Authors would like to extend their gratitude to the Director, CIAE, and the Head, Irrigation and Drainage Engineering Division, CIAE, Bhopal for permitting them to do this research work on drip irrigated rice crop management. Authors are also grateful to Dr. Norman Uphoff, Cornell University, US, for his valuable inputs in finalizing the manuscript.

Conflict of Interest:The authors declare that they have no conflict of interest. 


\section{REFERENCES}

[1] Belder, P., Bouman, B.A.M., Cabangon, R.. Lu. G., Quilang, E.J.P., Li, Y., Spiertz, J.H.J., Tuong, T.P. (2004):Effect of water saving irrigation on rice yield and water use in typical lowland conditions in Asia. - Agric. Water Manage. 65:193-210.

[2] Borrel, A., Garside, A., Fukai, S. (1997): Improving efficiency of water-use for irrigated rice in a semi-arid tropical environment. - Field Crops Res. 52: 231-248.

[3] Dass, A., Chandra, S. (2013): Irrigation, spacing and cultivar effects on net photosynthetic rate, dry matter partitioning, and productivity of rice under system of rice intensification in mollisols of northern India. - Expl. Agri. 49(4): 504-523.

[4] Dawe, D., Dobermann, A., Ladha, J.K., Yadav, R.L., Lin, B., Lal, P., Panaullah, G., Sariam, O., Singh, Y., Swarup, A., Zhen, Q.X. (2003): Does organic matter improve the sustainability and profitability of intensive rice systems. - Field Crops Res. 83:191- 213.

[5] Gani, A. (2001): Improving water-use efficiency for sustainable rice production systems. - In: Proc. International workshop on Water Saving Rice Production Systems. Nanjing University, China. April 2-4, 2001. Wageningen University and Research Center, Wageningen, Netherlands.

[6] Osaki, M., Shinano, T. M. M., Zheng, T., Tadano, T. (1997): A root-shoot interaction hypothesis for high productivity of field crops. - Soil Sci. Plant Nutr. 43: 1079- 1084.

[7] Riaz, A. (2001): Crop Management in Pakistan. - Department of Agriculture, Government of Punjab, Lahore.

[8] Saharawat, K.L. (2000): Elemental composition of the rice plant as affected by iron toxicity under field conditions. Commun. - Soil Sci. Plant Anal. 132: 2819-2827.

[9] Sato, S., Uphoff, N. (2007): A review of on-farm evaluation of system of rice intensification methods in eastern Indonesia. - CAB Reviews: Perspectives in Agriculture, Veterinary Science, Nutrition and Natural Resources 2: 12.

[10] Satyanarayan, A., Thiyagarajan, T.M., Uphoff, N. (2007): Opportunities for water saving with higher yield from the system of rice intensification. - Irrigation Science 25:99-115.

[11] Sharda, R., Mahajan, G., Siag, M., Singh, A. (2016): Performance of drip irrigated dryseeded rice (Oryza sativa L.) in South Asia. - Paddy and Water Environment (10):10071033.

[12] Steel, R.G.D., Torrie, J.H., Dicky, D.A. (1997): Principles and Procedures of Statistics: A Biometrical Approach, $3^{\text {rd }}$ Ed. - McGraw Hill Book Co. Inc., New York, USA.

[13] Stoop, W.A., Uphoff, N., Kassam, A. (2002): A review of agricultural research issues raised by the system of rice intensification (SRI) from Madagascar: Opportunities for improving farming systems for resource poor farmers. - Agric. Systems 71: 249-274.

[14] Uphoff, N., Kassam, A., Thakur, A. (2013): Challenges of increasing water saving and water productivity in the rice sector: introduction to the system of rice intensification (SRI). - Taiwan Water Conservancy 61 (4): 1-13.

[15] Uphoff, N., Fernandes, E.C.M., Yuan, L.P., Peng, J.M., Rafaralahy, S., Rabenandrasana, J. (2002): Assessment of the System of Rice Intensification (SRI). - Proc. International Conference, Sanya, China, Cornell International Institute for Food, Agriculture and Development (CIIFAD). Ithaca, NY. Pp. 140-142.

[16] Venkateswarlu, B., Hari, K., Katyl, J.C. (1997): Influence of soil and crop factors on the native rhizobia populations in soils under dry land farming. - Appl. Soil Ecol. 7:1-10.

[17] Yang, C., Yang, L., Yang, Y. Ouyang, Z. (2004): Rice root growth and nutrient uptake as influenced by organic manure in continuously and alternatively flooded paddy land. Agric. Water Manage. 70(1): 67- 81. 